\title{
Inhibition of germination and early growth of rape seed (Brassica napus L.) by MCPA in anionic and ester form
}

\author{
Justyna T. Polit • Tadeusz Praczyk • \\ Juliusz Pernak • Lukasz Sobiech • Ewa Jakubiak • \\ Grzegorz Skrzypczak
}

Received: 7 March 2013/Revised: 24 November 2013/Accepted: 25 November 2013/Published online: 15 December 2013

(C) The Author(s) 2013. This article is published with open access at Springerlink.com

\begin{abstract}
MCPA (4-chloro-2-methylphenoxy) acetic acid is a common synthetic auxin used as a herbicide. The purpose of this study was to determine the effects of four new forms of MCPA being the herbicidal ionic liquids (HILs) with MCPA as an anion and two previously known formulations (potassium-sodium salt and 2-ethylhexyl ester) on seed germination and seedling development of winter oilseed rape (Brassica napus). Rape plants are susceptible to MCPA and volunteers can be a big problem in crop rotation. Seedling fresh weight and root length were quantified, mitotic activity, as well as lipid, starch, hydrogen peroxide and polyphenol contents were assessed by light and fluorescence microscopy and the computer-aided cytophotometer. In primary roots mitotic activity was almost completely inhibited under the influence of herbicides, cell elongation zones and root hair zones were significantly reduced, and a characteristic bolded root segment formed
\end{abstract}

Communicated by A. Gniazdowska-Piekarska.

J. T. Polit ( ()

Department of Cytophysiology, Faculty of Biology and Environmental Protection, University of Łódź,

Pomorska 141/143, 90-236 Łódź, Poland

e-mail: politj@biol.uni.lodz.pl

T. Praczyk · E. Jakubiak

Institute of Plant Protection, National Research Institute, Wł.

Węgorka 20, 60-318 Poznań, Poland

J. Pernak

Poznan University of Technology, pl. Sklodowskiej-Curie 2, 60-965 Poznań, Poland

Ł. Sobiech · G. Skrzypczak

Agronomy Department, Poznań University of Life Sciences,

Dojazd 11, 60-632 Poznań, Poland just above a meristem. In contrast to the traditional salt formulation the new HILs were weak inducers of hydrogen peroxide synthesis, but were potent stimulators of the synthesis of phenolic compounds and storage as well as emergency substances such as lipids and starch. All tested forms of MCPA caused strong phytotoxic effect on winter rape seedlings, but the tested HILs were more effective.

Keywords Autofluorescence of phenols - Auxin herbicides · Hydrogen peroxide - Ionic liquids · Root meristems $\cdot$ Seed germination

\section{Introduction}

Synthetic auxins such as phenoxycarboxylic acids (MCPA, mecoprop, 2,4-D), benzoic acids (dicamba) and pyridinecarboxylic acids (picloram, clopyralid, fluroxypyr) are widely used in agriculture and horticulture as selective herbicides for mostly postemergence control of annual and perennial broad-leaved weeds (Praczyk et al. 2012). Synthetic auxins act similar to indole-3-acetic acid (IAA), but in contrast to natural phytohormones their degradation in plants occurs slowly (Grossmann 2000). They are absorbed by the leaves or roots, translocated via plant conducting system (xylem and phloem) to the meristematic regions and cause stem twisting, leaf epinasty, inhibition of shoot and root growth and finally cells death. However, the specific site of herbicide action is not well known. It is thought that they are active at multiple levels, among others, they disrupt hormone balance, nucleic acid metabolism and protein synthesis (Monaco et al. 2002). The primary action of synthetic auxins includes also cell wall loosening by increasing the activity of the proton pump that causes the reduction of apoplasmic $\mathrm{pH}$ (Senseman 2007). The recent studies showed that there was a 
specific interaction between auxin, ethylene and the abscisic acid biosynthesis (for review see Grossmann 2010).

The purpose of this study was to determine the effects of MCPA on seed germination and seedling development of dicotyledonous plants on the example of winter oilseed rape (Brassica napus L. ssp. napus). The choice of rape as a model plant was motivated by the fact that rape plants are susceptible to MCPA and volunteers can be a big problem in crop rotation. In our study, we used four new formulations of MCPA being the herbicidal ionic liquids with MCPA as an anion and two known formulations, namely the sodium-potassium salt and 2-ethylhexyl ester.

Ionic liquids (ILs) are defined as organic salts composed entirely of ions that are liquid below $100{ }^{\circ} \mathrm{C}$ (Rogers and Seddon 2003a, b; Wasserscheid and Welton 2008; Kirchner 2009; Olivier-Bourbigou et al. 2010). They possess unique properties like low vapour pressure, reasonably good conductivity, wide liquid range, as well as high thermal and electrochemical stability and are excellent solvents for a wide range of compounds. ILs have been receiving considerable global attention in recent years due to their potential application (Plechkova and Seddon 2008). Their negligible vapour pressure and non-inflammability reduce or eliminate the risk of polluting emissions to air. The evaluation of ILs proceeds very quickly from the first generation (ILs with unique tuneable physical properties) to the second generation (ILs with targeted chemical properties combined with selected physical properties), and to the third generation (ILs with targeted biological properties combined with selected physical and chemical properties; Hough and Rogers 2007; Hough et al. 2007). The newest third generation ILs was enriched with phytopharmaceuticals called herbicidal ionic liquids (HILs) in which MCPA (Pernak et al. 2011) and 2,4-D are anions (Praczyk et al. 2012). They exhibit higher biological activity than currently used salts of MCPA and 2,4-D. Herbicidal ionic liquids have chemical and thermal stability and show substantially lower water solubility thus reducing soil and groundwater mobility. Acute toxicity of HILs could be controlled by appropriate selection of cation type (Pernak et al. 2011). These novel forms of phenoxy acids possess reduced volatility and drift potential. Ionic liquids are still fairly innovative solvents.

\section{Materials and methods}

Plant material

The certificated seeds of winter rape (Brassica napus L.) cv. Libomir with germination capacity of $98 \%$ have been used both in laboratory and glasshouse experiments.

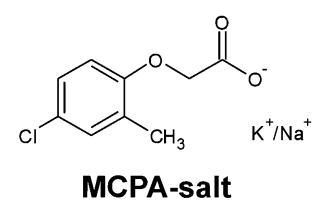<smiles>CCCCC(CC)COC(=O)COc1ccc(Cl)cc1C</smiles><smiles>Cc1cc(Cl)ccc1OCC(=O)O</smiles>

HIL-1<smiles>Cc1cc(Cl)ccc1OCC(=O)O</smiles>

HIL-3<smiles>Cc1cc(Cl)ccc1OCC(=O)O</smiles>

HIL-2

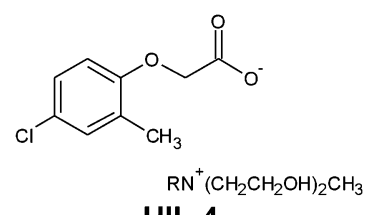

HIL-4
Fig. 1 Structures of chemicals used

\section{Chemicals}

Two commercial formulations of MCPA: MCPA-salt (Chwastox Extra $300 \mathrm{SL}^{\circledR}$ containing MCPA as sodiumpotassium salt) and MCPA-ester (Chwastox AS $600 \mathrm{EC}^{\circledR}$ containing MCPA as ester 2-ethylhexyl) as well as four new HILs with MCPA as an anion were used (Fig. 1). HILs were obtained according to the method recently described (Pernak et al. 2011). All prepared HILs were characterized by ${ }^{1} \mathrm{H}$ NMR, ${ }^{13} \mathrm{C}$ NMR. ${ }^{1} \mathrm{H}$ NMR spectra were recorded on a Mercury Gemini 300 spectrometer operating at $300 \mathrm{MHz}$ with tetramethylsilane as the internal standard. ${ }^{13} \mathrm{C}$ NMR spectra were obtained with the same instrument at $75 \mathrm{MHz}$.

Didecyldimethylammonium (4-chloro-2methylphenoxy)acetate-HIL-1

${ }^{1} \mathrm{H} \mathrm{NMR}\left(\mathrm{CDCl}_{3}\right) \delta \mathrm{ppm}=0.88(\mathrm{t}, J=6.7 \mathrm{~Hz}, 6 \mathrm{H}), 1.25$ $(\mathrm{m}, 28 \mathrm{H}), 1.57(\mathrm{q}, J=6.9 \mathrm{~Hz}, 4 \mathrm{H}), 2.24(\mathrm{~s}, 3 \mathrm{H}), 3.12(\mathrm{~s}$, $6 \mathrm{H}), 3.21(\mathrm{t}, J=8.5 \mathrm{~Hz}, 4 \mathrm{H}), 4.41(\mathrm{~s}, 2 \mathrm{H}), 6.75(\mathrm{~d}$, $J=8.8 \mathrm{~Hz}, 1 \mathrm{H}), 7.00\left(\mathrm{dd}, J^{1,2}=0.6 \mathrm{~Hz}, J^{2,3}=2.2 \mathrm{~Hz}\right.$, $1 \mathrm{H}), 7.04(\mathrm{~d}, J=0.6 \mathrm{~Hz}, 1 \mathrm{H}) ;{ }^{13} \mathrm{C}$ NMR $\delta \mathrm{ppm}=14.0$, $16.3,22.5,22.52,26.1,29.06,29.12,29.26,29.30,31.7$, 51.1, 63.3, 68.4, 112.7, 124.1, 126.0, 128.4, 129.9, 156.1, 173.1,

Dicocodimethylammonium (4-chloro-2methylphenoxy)acetate-HIL-2

${ }^{1} \mathrm{H} \mathrm{NMR}\left(\mathrm{CDCl}_{3}\right) \delta \mathrm{ppm}=0.88(\mathrm{t}, J=6.7 \mathrm{~Hz}, 6 \mathrm{H}), 1.25$ $(\mathrm{m}, 44 \mathrm{H}), 1.57(\mathrm{q}, J=6.9 \mathrm{~Hz}, 4 \mathrm{H}), 2.24(\mathrm{~s}, 3 \mathrm{H}), 3.13(\mathrm{~s}$, $6 \mathrm{H}), 3.18(\mathrm{t}, J=4.4 \mathrm{~Hz}, 4 \mathrm{H}) ; 4.39(\mathrm{~s}, 2 \mathrm{H}), 6.75(\mathrm{~d}$, $J=8.5 \mathrm{~Hz}, 1 \mathrm{H}), 7.02(\mathrm{~d}, J=2.8 \mathrm{~Hz}, 1 \mathrm{H}), 7.05(\mathrm{~s}, 1 \mathrm{H})$, 
${ }^{13} \mathrm{C}$ NMR $\delta \mathrm{ppm}=14.1,16.4,22.6,26.2,29.1,29.26$, $29.29,29.34,29.4,29.54,29.59,29.63,31.8,51.2,63.3$, $68.5,112.7,123.9,125.9,128.3,129.8,156.0,172.9$,

Dicocotrimethylammonium (4-chloro-2methylphenoxy)acetate-HIL-3

${ }^{1} \mathrm{H} \mathrm{NMR}\left(\mathrm{CDCl}_{3}\right) \delta \mathrm{ppm}=0.88(\mathrm{t}, J=6.7 \mathrm{~Hz}, 3 \mathrm{H}), 1.23$ $(\mathrm{m}, 22 \mathrm{H}), 1.55(\mathrm{q}, J=3.8 \mathrm{~Hz}, 2 \mathrm{H}), 2.21(\mathrm{~s}, 3 \mathrm{H}), 3.08(\mathrm{~s}$, $9 \mathrm{H}), 3.15(\mathrm{t}, J=4.3 \mathrm{~Hz}, 2 \mathrm{H}), 4.36(\mathrm{~s}, 2 \mathrm{H}), 6.72(\mathrm{~d}$, $J=8.2 \mathrm{~Hz}, 1 \mathrm{H}), 7.02(\mathrm{~d}, J=3.3 \mathrm{~Hz}, 1 \mathrm{H}), 7.04(\mathrm{~s}, 1 \mathrm{H})$, ${ }^{13} \mathrm{C}$ NMR $\delta \mathrm{ppm}=14.1,16.4,22.7,23.0,26.3,29.25$, 29.30, 29.4, 29.5, 29.6, 29.7, 31.9, 52.9, 66.6, 68.4, 112.7, $124.1,126.0,128.3,129.9,155.9,173.1$,

Cocodi(2-hydoxyethyl)methylammonium (4-chloro-2methylphenoxy)acetate-HIL-4

${ }^{1} \mathrm{H} \mathrm{NMR}\left(\mathrm{CDCl}_{3}\right) \delta \mathrm{ppm}=0.88(\mathrm{t}, J=6.7 \mathrm{~Hz}, 3 \mathrm{H}), 1.24$ $(\mathrm{m}, 22 \mathrm{H}), 1.58(\mathrm{q}, J=3.8 \mathrm{~Hz}, 2 \mathrm{H}), 2.23(\mathrm{~s}, 3 \mathrm{H}), 3.07$ (s, $3 \mathrm{H}), 3.29(\mathrm{t}, J=5.8 \mathrm{~Hz}, 2 \mathrm{H}), 3.45(\mathrm{t}, J=5.6 \mathrm{~Hz}, 4 \mathrm{H})$, $3.92(\mathrm{t}, J=4.4 \mathrm{~Hz}, 4 \mathrm{H}), 4.39(\mathrm{~s}, 2 \mathrm{H}), 5.32(\mathrm{~s}, 1 \mathrm{H}), 6.70(\mathrm{~d}$, $J=8.5 \mathrm{~Hz}, 1 \mathrm{H}), 7.04(\mathrm{~d}, J=2.8 \mathrm{~Hz}, 1 \mathrm{H}), 7.06(\mathrm{~s}, 1 \mathrm{H})$, ${ }^{13} \mathrm{C}$ NMR $\delta \mathrm{ppm}=14.1,16.4,22.5,22.7,26.4,29.2,29.3$, $29.48,29.51,29.59,29.61,29.7,31.8,31.9,49.9,55.5$, $63.6,64.1,68.2,112.5,124.4,126.0,128.6,130.0,155.7$, 174.0 .

Application of herbicides, seed germination and culture

In laboratory and glasshouse experiments the influence of MCPA forms on the germination and early growth of winter rape seedlings has been evaluated. HIL-3 and HIL-4 were dissolved in water; however, HIL-1 and HIL-2 were dissolved in a water and ethanol solution (3:1). These new forms of MCPA were compared with the commercial herbicides described above. They were applied on the surface of seeds using a spray chamber with flat fan nozzle type F $110 / 0-6 / 3110^{\circ}$ LD-015 and an operating pressure of $0.2 \mathrm{MPa}$. The concentration of all tested substances was established on $0.2 \%$ (v/v), which was similar to $400 \mathrm{~g}$ of MCPA per 1 ha with the water volume carrier of $200 \mathrm{~L} / \mathrm{ha}$. The experimental design was a randomized complete block with four replications. All experiments were repeated.

In experiments carried out in Petri dishes the seeds of winter rape were sown on wet filter paper (25 seeds per dish), and after application of herbicides they were incubated at $20{ }^{\circ} \mathrm{C}$ in darkness for 5 days. After that the seedlings in Petri dishes were grown with 16 -h photoperiod (16 h of light $-13,000 \mathrm{~lx}$ and $8 \mathrm{~h}$ of darkness). In experiments carried out in greenhouse the seeds of winter rape were placed on the surface of a sandy loam soil in $0.5-\mathrm{L}$ plastic pots (25 seeds per pot). After application of herbicides all pots were placed in a greenhouse at temperature $20{ }^{\circ} \mathrm{C}\left( \pm 3{ }^{\circ} \mathrm{C}\right)$ and a 16 -h photoperiod. Fresh weight of seedlings was measured 2 weeks (for Petri dishes culture) or 3 weeks (for greenhouse culture) after the herbicide application. The results were expressed as the percent of fresh weight reduction compared with untreated plants.

\section{Feulgen staining}

Seedlings were fixed in cold Carnoy's mixture of absolute ethanol and glacial acetic acid $(3: 1 ; \mathrm{v} / \mathrm{v})$ for $1 \mathrm{~h}$, washed several times with ethanol, rehydrated, hydrolysed in $4 \mathrm{M}$ $\mathrm{HCl}$ for $1 \mathrm{~h}$ and stained with Schiff's reagent (pararosaniline; Sigma-Aldrich) according to the standard methods (Maszewski and Kaźmierczak 1998). After rinsing in $\mathrm{SO}_{2}$ water (three times) and distilled water, 1-mm-long apical segments of roots were cut off, placed in a drop of $45 \%$ acetic acid and squashed onto Super-Frost (Menzel-Gläser, Braunschweig, Germany) microscope slides. Following freezing with dry ice, coverslips were removed, and the dehydrated dry slides were embedded in Canada balsam.

$\mathrm{H}_{2} \mathrm{O}_{2}$ detection by the DAB-uptake method

The experimental procedure was performed according to Thordal-Christensen et al. (1997) with some modifications. Three-day-old seedlings of $B$. napus were incubated in a solution containing $1 \mathrm{mg} \mathrm{mL}^{-1}$ DAB $\left(3,3^{\prime}\right.$ diaminobenzidine) dissolved in Tris buffer $(10 \mathrm{mM}$ Tris, $10 \mathrm{mM}$ EDTA-2Na, $100 \mathrm{mM} \mathrm{NaCl}, \mathrm{pH} \mathrm{7.6)}$ for $12 \mathrm{~h}$. Then roots were fixed for $40 \mathrm{~min}\left(4^{\circ} \mathrm{C}\right)$ in PBS-buffered $4 \%$ paraformaldehyde solution, washed three times with PBS and placed in a citric acid-buffered digestion solution ( $\mathrm{pH}$ 5.0) containing $2.5 \%$ pectinase, $2.5 \%$ cellulose and $2.5 \%$ pectolyase, and incubated at $37^{\circ} \mathrm{C}$ for $25 \mathrm{~min}$. After that the roots were washed as before, rinsed with distilled water and squashed onto glass slides.

Cytochemical localization of lipids and starch

Cytochemical detection of lipids and starch content in root cells was performed using standard procedure of staining with the mixture of Sudan III and IV or Lugol's iodine solution, respectively.

Polyphenols autofluorescence

Several classes of phenolics are autofluorescent under UV light (Schoenwaelder 2008). Seeds were fixed for $1 \mathrm{~h}$ in $4 \%(\mathrm{v} / \mathrm{v})$ buffered formaldehyde with PBS (pH 7.0) at 

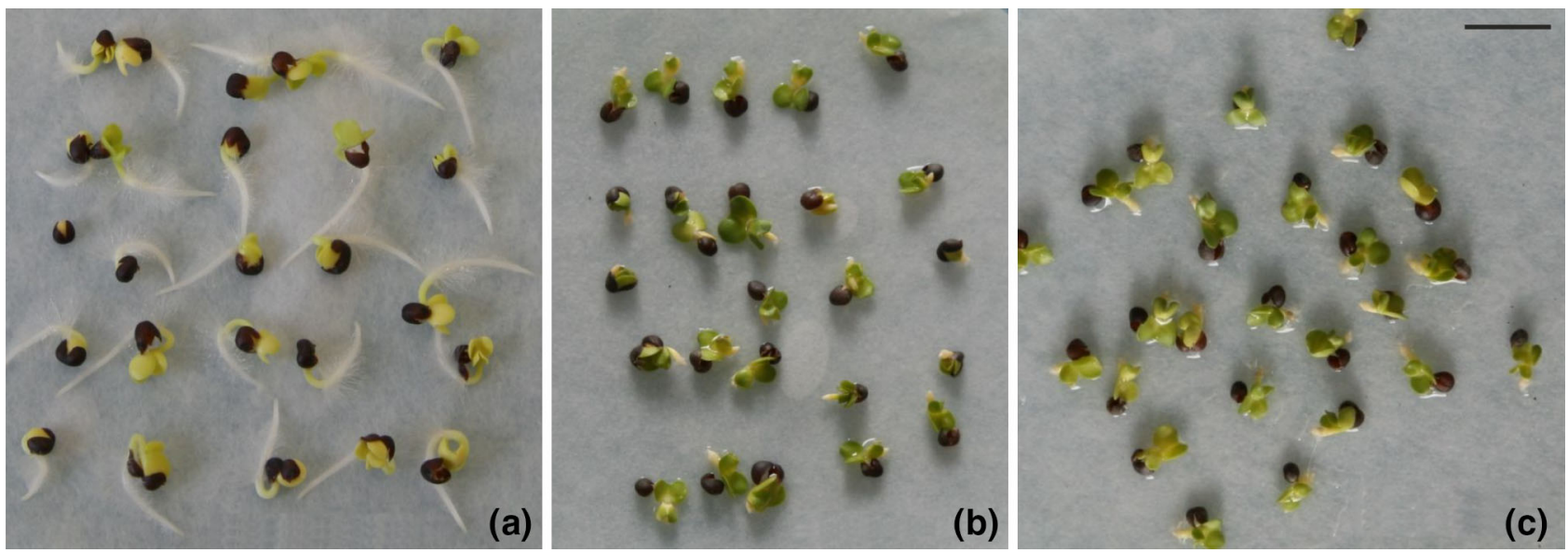

Fig. 2 Effect of different forms of MCPA on early growth of B. napus seedlings (5 days after application). a Control, b MCPA-ester, $\mathbf{c}$ HIL-3. Bar $10 \mathrm{~mm}$

$4{ }^{\circ} \mathrm{C}$. Than they were rinsed in PBS three times, dehydrated in a graded ethanol, embedded in paraplast and ultrathin sections $(5-7 \mu \mathrm{m})$ were prepared using Mikrom microtome. Deparaffinisation was performed by heating in $60{ }^{\circ} \mathrm{C}$ and washing in xylene, and then sections were hydrated. Staining was performed using $0.1 \%$ toluidine blue in sodium chloride. Slides were washed three times in distilled water, dehydrated in ethanol gradient $75-100 \%$ and cleared in xylene.

\section{Observations, analyses and statistics}

Observations of whole seedlings as well as analyses of mitotic activity, lipid, starch and hydrogen peroxide contents in the cells were performed using binocular microscope SMZ-2T (Nikon) and Optiphot-2 microscope (Nikon) containing phase-contrast optics, respectively, equipped with DXM 1200 CCD camera (Nikon).

Observations of polyphenol autofluorescence were performed using Eclipse E-600 epifluorescence microscope (Nikon) equipped with UV filter $(\lambda=340-380)$ and DSFil CCD camera (Nikon).

To evaluate differences in lipid, polyphenol and hydrogen peroxide levels, all images were recorded at exactly the same time of integration. Semiquantitative measurements of the above-mentioned substances staining were made using the computer-aided Cytophotometr V1.2 (Forel, Poland) after converting colour images into grey scale and expressed in arbitrary units as mean pixel value (pv) spanning the range from 0 (white) to 255 (dark). Each mean value $( \pm \mathrm{SD})$ was based on the analysis of five root meristems (100 cells/meristems). Statistical Student's $t$ test was used to establish the significance of the differences between the values. The most typical effects were recorded and are presented as a photo.

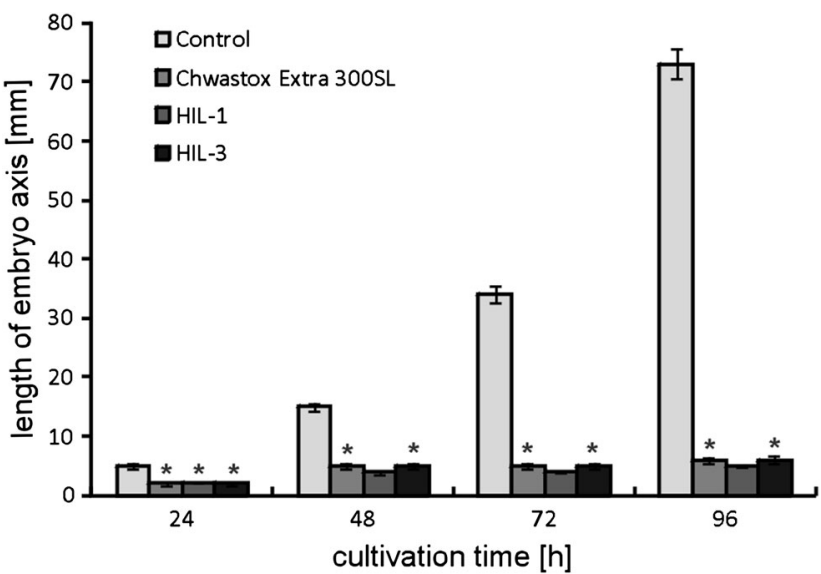

Fig. 3 Average length (mm) $\pm \mathrm{SD}$ of the embryo axis of $B$. napus seedlings (root + hypocotyls without cotyledons) after 24, 48, 72 and $96 \mathrm{~h}$ of culture in distilled water. Before sowing the seeds were either soaked in distilled water (Control) or in the solutions of various herbicides: MCPA-salt (Chwastox Extra $300 \mathrm{SL}^{\circledR}$ ) and MCPA in anion (HIL-1, HIL-3). Stars show the results where the differences are not statistically significant $(P=0.05)$

\section{Results}

Morphological analysis of seedlings

Initially, the tested forms of MCPA applied on the surface of winter rape seeds similarly disturbed growth and development of seedlings (Fig. 2). Morphological analyses revealed that MCPA-salt, HIL-1 and HIL-3, regardless of their chemical form caused a significant (almost 14-fold after $96 \mathrm{~h}$ of culture) inhibition of seedling growth in comparison with the control. The difference in the size of seedlings was mainly due to a significant reduction of root growth (Figs. 3, 4a-d). In the roots under the influence of herbicides cell elongation zone and root hair zone were significantly reduced (Fig. 4a-d). Moreover, after 96 h of 

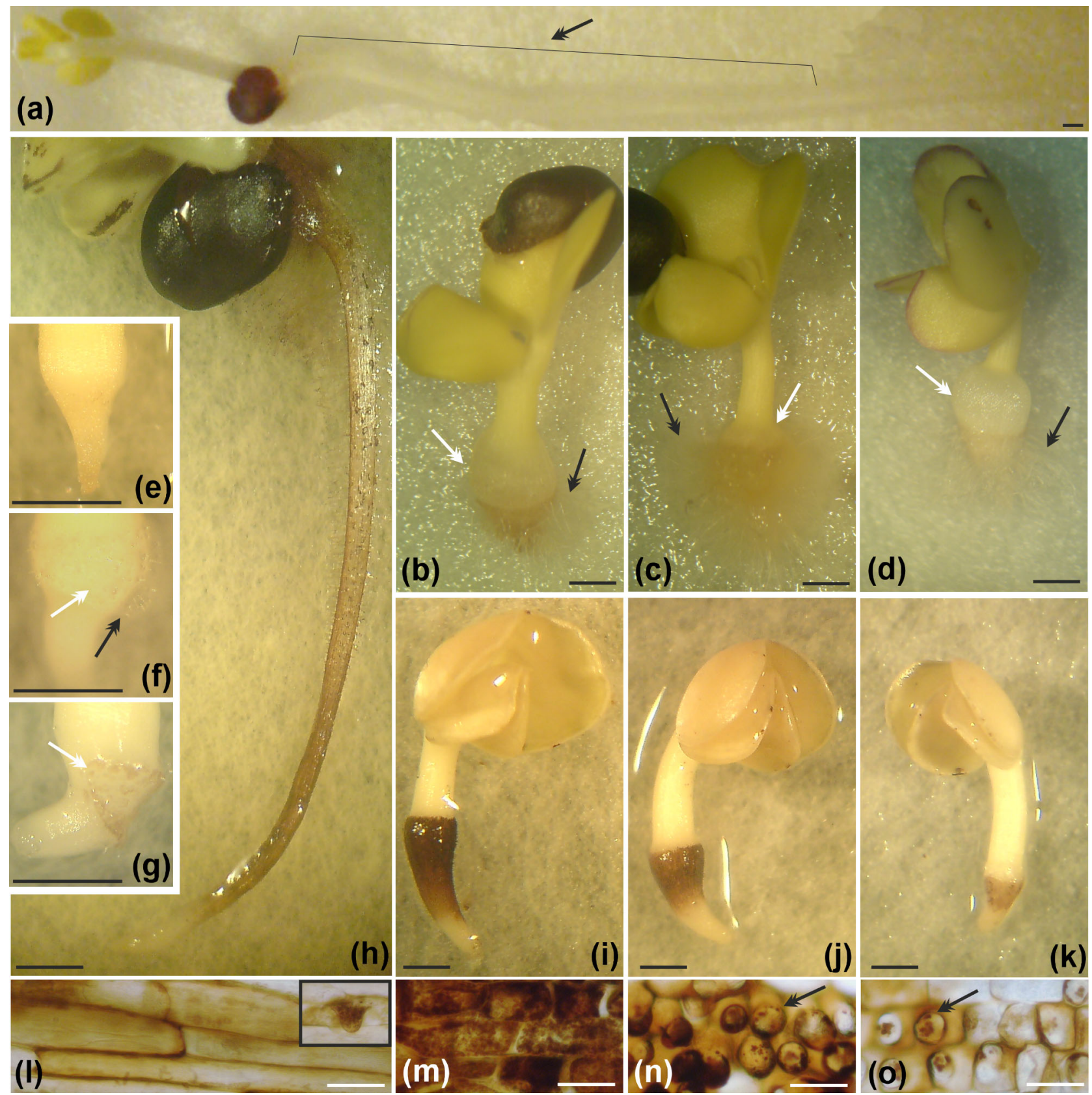

Fig. 4 Morphological differences of B. napus seedlings after $96 \mathrm{~h}$ of culture in distilled water (a-d) as well as differences in the production of hydrogen peroxide released in the reaction with $\mathrm{DAB}$ in the roots (h-k) and root epidermal cells (l-o) of 3-day-old seedlings. Before sowing the seeds were either soaked in distilled water (Control; $\mathbf{a}, \mathbf{h}$, l) or in the solutions of various herbicides: MCPA-salt (Chwastox

Extra $\left.300 \mathrm{SL}^{\circledR} ; \mathbf{b}, \mathbf{i}, \mathbf{m}\right)$, MCPA in anion HIL-1 (c, j, n) and HIL-3 (d, $\mathbf{k}, \mathbf{o})$. Differences in the structure of root apex of the seedlings grown from the seeds treated with HIL-2 (e, f, g); black arrows indicate the zone of root hairs, and white arrows indicate bolded zone in the immediate vicinity of meristems. Black bar $1 \mathrm{~mm}$, white bar $100 \mu \mathrm{m}$

culture, a characteristic protruding section of the root formed just above the meristems. This protruding fragment was the largest in the roots previously treated with HIL-3 (Fig. 4d). During its formation roots often cracked which in consequence led to desiccation and meristem death (Fig. $4 \mathrm{e}-\mathrm{g}$ ).

After 2 weeks of culture in Petri dishes reduction of fresh weight of the seedling whose seeds were treated with HILs varied from 51 to $63 \%$. Reduction of fresh weight of the seedling whose seeds were treated with commercial forms of MCPA was similar and varied from 55 to $61 \%$ in comparison with the untreated control plants (Table 1). 
Table 1 The influence of different forms of MCPA on fresh weight reduction of winter rape seedlings (Petri dishes experiment-as compared to untreated control)

\begin{tabular}{lll}
\hline Treatments & Mean $(\%)$ & Range $(\%)$ \\
\hline HIL-1 & 51 & $50-51$ \\
HIL-2 & 51 & $47-54$ \\
HIL-3 & 63 & $61-64$ \\
HIL-4 & 56 & $51-60$ \\
MCPA-salt & 61 & $56-66$ \\
MCPA-ester & 55 & $54-55$ \\
\hline
\end{tabular}

Table 2 The influence of different forms of MCPA on fresh weight reduction of winter rape seedlings (greenhouse experiment)

\begin{tabular}{lll}
\hline Treatments & Mean $(\%)$ & Range $(\%)$ \\
\hline HIL-1 & 83 & $81-86$ \\
HIL-2 & 86 & $82-95$ \\
HIL-3 & 78 & $59-98$ \\
HIL-4 & 75 & $51-89$ \\
MCPA-salt & 66 & $61-72$ \\
MCPA-ester & 68 & $63-77$ \\
\hline
\end{tabular}

Moreover, the treatments with HILs additionally caused the chlorosis of cotyledons.

Long-term studies conducted in the greenhouse revealed that all tested HILs were more phytotoxic than MCPA-salt or MCPA-ester (Table 2). They caused reduction of seedling fresh weight from 75 to $86 \%$, while the commercial forms of MCPA from 66 to $68 \%$. HIL-2 exhibited the highest biological activity.

\section{Hydrogen peroxide content}

In the control plants brown polymers of DAB (indicating the presence of hydrogen peroxide) were seen in the root epidermis of cell differentiation and root hair zones (Fig. 4h). Elongated epidermal cells were clearly and homogeneously stained indicating a relatively low level of $\mathrm{H}_{2} \mathrm{O}_{2}$ in these cells (Figs. 41, 5). DAB polymers were mainly localized in the wall and, in smaller amounts, in the cytoplasm of root hair cells. MCPA-salt was the potent inducer of $\mathrm{H}_{2} \mathrm{O}_{2}$ formation. It triggered intense production of $\mathrm{H}_{2} \mathrm{O}_{2}$ in the root hair zone and cell elongation zone (Figs. 4i, 5). Epidermal cells with limited length were all filled with dark-brown DAB polymers (Fig. $4 \mathrm{~m}$ ). Slightly weaker accumulation of $\mathrm{H}_{2} \mathrm{O}_{2}$ was observed in the root hair zone and cell elongation zone under the influence of HIL-1 (Figs. 4j, 5) much shorter epidermal cells of these roots contained DAB polymers mainly in the root hair formation sites (Fig. 4n). The lowest content of $\mathrm{H}_{2} \mathrm{O}_{2}$ expressed as the quantity of polymerised $\mathrm{DAB}$ was observed in the roots

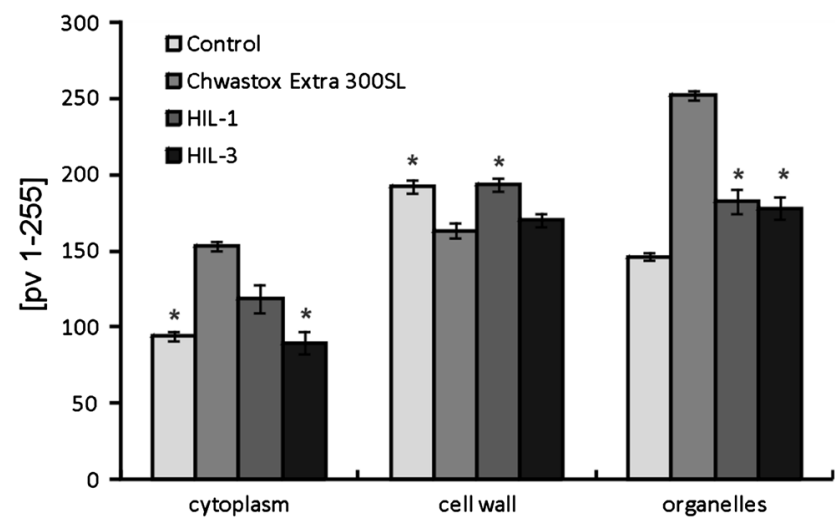

Fig. 5 Semiquantitative measurements of hydrogen peroxide staining at the area of cytoplasm, cell wall and organelles in root meristem cells of B. napus seedlings after $72 \mathrm{~h}$ of culture, expressed as mean pixel value (pv) spanning the range from 0 (white) to 255 (dark) $\pm \mathrm{SD}$. Before sowing the seeds were either soaked in distilled water (Control) or in the solutions of various herbicides: MCPA-salt (Chwastox Extra 300SL ${ }^{\circledR}$ ) and MCPA in anion (HIL-1, HIL-3). Stars show the results where the differences are not statistically significant $(P=0.05)$

under HIL-3 influence (Fig. 5). Clearly the shortest epidermal cells of these roots contained $\mathrm{DAB}$ polymers mainly within the root hair zone (Fig. $4 \mathrm{k}$, o).

\section{Phenol content}

Autofluorescence of the cross-sections of roots revealed differences in the localization and content of phenolic compounds (Figs. 6, 7). In the control cells, the blue autofluorescence induced by UV light was detected mainly in small vesicles or in a tubular network of endoplasmic reticulum (Fig. 6a-d). After the interference of the herbicides phenols accumulated mainly in relatively numerous large vacuoles. The content of phenols in the vacuoles was much higher in the cells coming from the HIL-treated seeds than in those treated with the traditional MCPA-salt (Figs. 6, 7e-h).

\section{Cytological analysis of cells}

Cytological staining of the control root meristems with Feulgen method revealed the presence of cells at each stage of cell cycle (Fig. 8a-g). The cytoplasm of these cells contained small high-density areas, which were visible in the phase-contrast microscope as opalising points (Fig. $8 \mathrm{a}^{\prime}-\mathrm{g}^{\prime}$ ). In root meristems under the influence of herbicides mitotic activity was almost completely inhibited (Fig. 9) and almost only interphase nuclei were observed (not shown). However, phase-contrast microscopy showed the presence of post-telophase cells joined by a common cell wall in the meristems coming from the seeds treated with HIL-3 (Fig. 8h, h'). Both the above-mentioned cells and others (not shown) contained significantly larger areas 

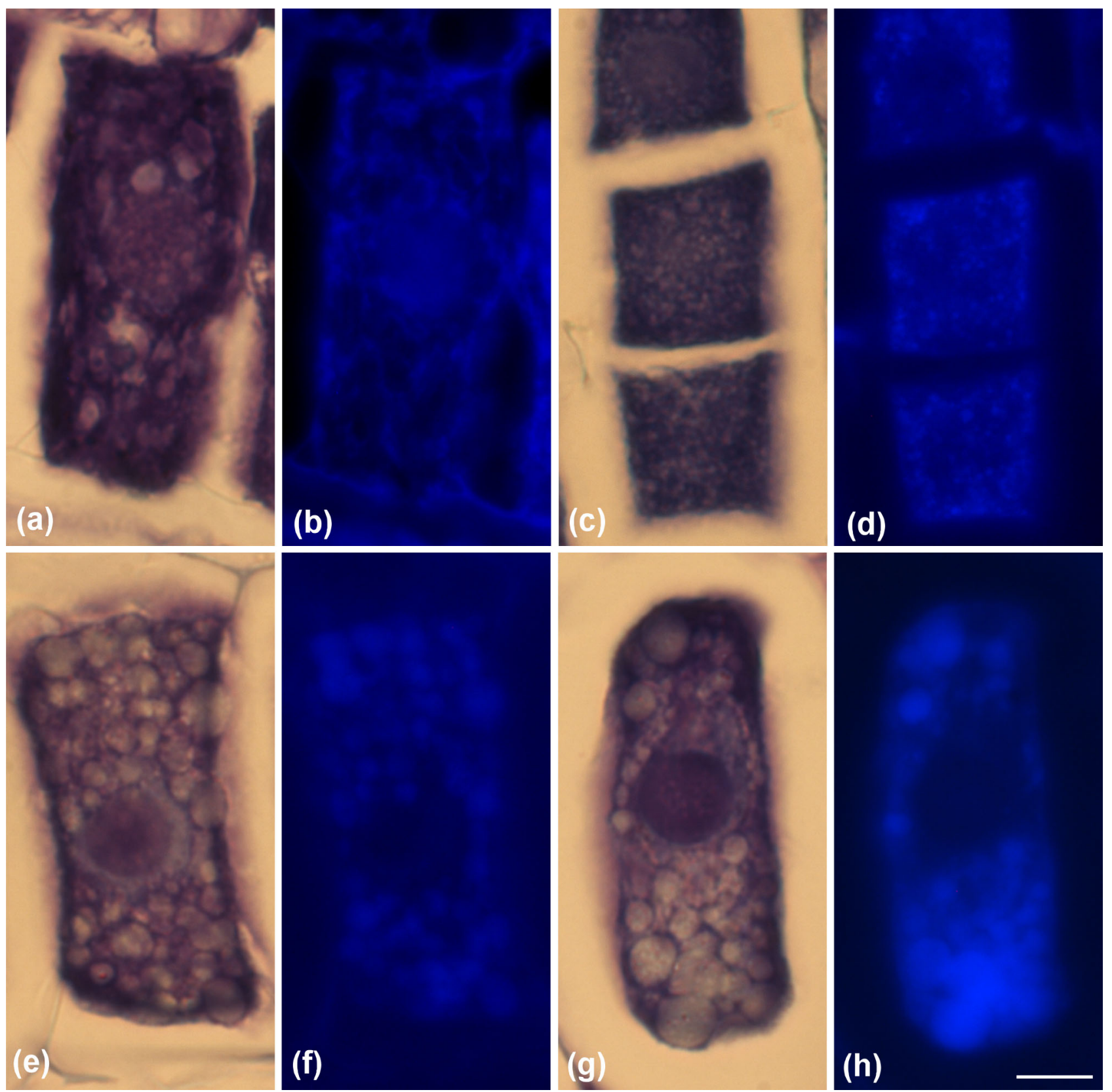

Fig. 6 Root meristem cells of B. napus stained with toluidine blue in the light microscope $(\mathbf{a}, \mathbf{c}, \mathbf{e}, \mathbf{g})$ as well as autofluorescence of polyphenols in these same cells under UV light in the fluorescence microscope $(\mathbf{b}, \mathbf{d}, \mathbf{f}, \mathbf{h})$. Cells derived from the seedlings grown from

the seeds previously soaked in distilled water (Control; a-d) or the solutions of herbicides: MCPA-salt (Chwastox Extra $\left.300 \mathrm{SL}^{\circledR} ; \mathbf{e}, \mathbf{f}\right)$

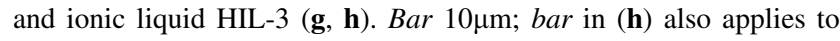
$(\mathbf{a}-\mathbf{g})$

of increased cytoplasm density in comparison with the control cells. Furthermore, in the protruding zone of roots large cells filled with numerous Feulgen-positive structures (Fig. 8i) as well as iridescent Feulgen-negative structures were observed (Fig. 8i').

Staining of the meristem cells and of those coming from the protruding zone with the mixture of Sudan III and IV revealed the presence of lipids, while staining with Lugol's revealed also starch grains (Fig. 10). Areas occupied by lipids coincided with those previously seen opalising in the

contrast-phase microscope, while, starch grains in plastids corresponded to Feulgen-positive areas. In the control meristem cells lipid substances were relatively less abundant than in the meristem cells affected by herbicides (Figs. 10a-d, 11). The most abundant lipids were accumulated in the meristem cells under the influence of HIL-3 (compare Fig. 10b-d). Similarly, the cells derived from the protruded zone were rich in lipids (Fig. 10f-h). Significant accumulation of emergency substances characterized also post-telophase cells which already ended the division of 


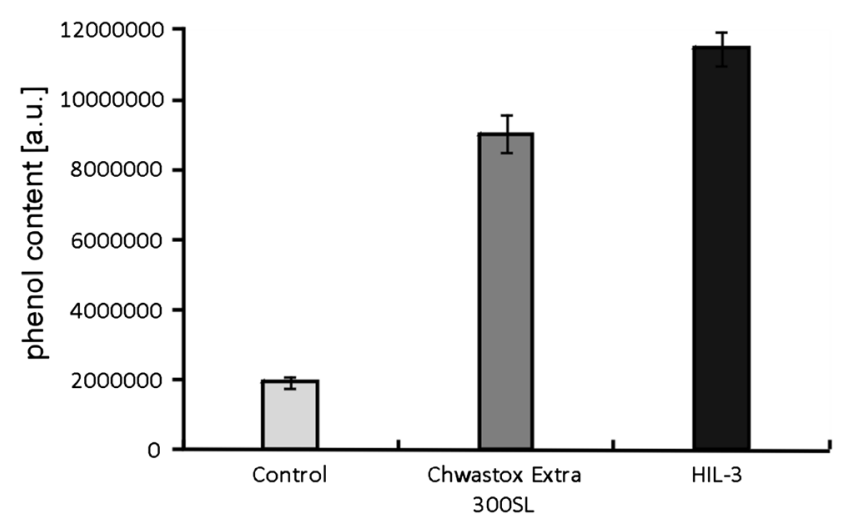

Fig. 7 Phenol content [arbitrary units, (a.u.)] \pm SD in root meristem cells of B. napus seedlings after $72 \mathrm{~h}$ of culture in distilled water. Before sowing the seeds were either soaked in distilled water (Control) or in the solutions of various herbicides: MCPA-salt (Chwastox Extra $300 \mathrm{SL}^{\circledR}$ ) and ionic liquid HIL-3

their nuclei but did not complete division of cytoplasm and were connected to a common cell wall (Fig. 10i-k).

\section{Discussion}

The current study aimed at comparing the impact of a traditional auxin herbicide, MCPA-salt and new MCPAionic liquids on the germination and growth of winter rape seedlings. It was shown that both formulations of MCPA caused similar morphological changes expressed in reduced growth and development of the roots and in consequence of whole seedlings, but it should be noted that MCPA-ionic liquid influence was stronger than that of MCPA-salt. The reason of this difference was looked for at the cellular level by assessing the contents of $\mathrm{H}_{2} \mathrm{O}_{2}$ and phenols and by analysing the activity of cell division, i.e. the parameters changing under the influence of different stress factors.

$\mathrm{H}_{2} \mathrm{O}_{2}$ serves as a signalling molecule activates defence responses to various stresses and is one of the constitutive attributes of plant root physiology. On the other hand, $\mathrm{H}_{2} \mathrm{O}_{2}$, like other highly reactive oxygen species (ROS), can disrupt normal metabolism through oxidative damage to lipids, proteins and nucleic acids (Dat et al. 2000; Neill et al. 2002; Vranová et al. 2002; Mittler et al. 2004; Gechev and Hille 2005; Cheng and Song 2006; Gapper and Dolan 2006; Kwak et al. 2006). Therefore, different antioxidative enzymes (e.g. peroxidases) play a key role in the ROS scavenging system. Peroxidases, depending on their chemical environment, can be considered as bifunctional in relation to $\mathrm{H}_{2} \mathrm{O}_{2}$. In the peroxidative cycle they catalyse the reduction of $\mathrm{H}_{2} \mathrm{O}_{2}$ (thus, converting $\mathrm{H}_{2} \mathrm{O}_{2}$ into water) by taking electrons from various donors: phenolic compounds, lignin precursors, auxin or secondary metabolites (thus oxidizing them; Passardi et al. 2004). Whereas in the
Fig. 8 Feulgen-stained root meristem cells $(\mathbf{a}-\mathbf{h})$ and cells derived from the bolded zone directly adjacent to the meristem (i) in the seedlings of B. napus after $72 \mathrm{~h}$ of culture in distilled water. Light (a$\mathbf{g}, \mathbf{h}, \mathbf{i})$ and phase-contrast $\left(\mathbf{a}^{\prime}-\mathbf{g}^{\prime}, \mathbf{h}^{\prime}, \mathbf{i}^{\prime}\right)$ microscopy. Before sowing the seeds were either soaked in distilled water (Control; a nucleus before mitosis, b prophase, $\mathbf{c}$ metaphase, $\mathbf{d}$ anaphase, e telophase, f post-telophase, $\mathbf{g}$ nucleus after mitosis) or in the solutions of ionic liquid HIL-3 (h-i), stars show structures with higher optical density, probably lipids in the cytoplasm, arrows indicate the cell wall between the post-telophase nuclei; $n$ nucleus, $p$ Feulgen-positive areas probably polysaccharides in plastids. Bar $10 \mu \mathrm{m} ;$ bar in $\left(\mathbf{g}^{\prime}\right)$ also applies $(\mathbf{a}-\mathbf{g})$ and $\left(\mathbf{a}^{\prime}-\mathbf{f}^{\prime}\right)$

hydroxylic cycle they can also promote the formation of $\mathrm{H}_{2} \mathrm{O}_{2}, \mathrm{OH}^{-}$or $\mathrm{O}_{2}^{--}$, provided that an appropriately strong reductant is present (Dunand et al. 2007). In our work $\mathrm{H}_{2} \mathrm{O}_{2}$ content was detected indirectly by the DAB-uptake method. DAB polymerizes giving brown staining of cells as soon as it comes into contact with $\mathrm{H}_{2} \mathrm{O}_{2}$ in the presence of endogenous peroxidase (Thordal-Christensen et al. 1997).

In the 3-day-old control seedlings of $B$. napus the presence of $\mathrm{H}_{2} \mathrm{O}_{2}$ was observed mainly in root hairs and also in the walls of root epidermal cells from the differentiation zone (where cell elongation ceases), but not in the root meristem and cell elongation zone. This is in line with the report showing that $\mathrm{H}_{2} \mathrm{O}_{2}$ is involved in root hair formation and in cell elongation restriction. $\mathrm{H}_{2} \mathrm{O}_{2}$ reduces root elongation by cross-linking cell wall constituents and diversification of cell wall composition (e.g. by lignin deposition; Foreman et al. 2003; Dunand et al. 2007). Under the influence of traditional MCPA a significant increase in $\mathrm{H}_{2} \mathrm{O}_{2}$ content (both in the cell differentiation and elongation zones) with simultaneous inhibition of cell and consequently root elongation were observed. The obtained results are consistent with the studies of Šimonovičová et al. (2004) showing that auxin herbicides caused oxidative stress and strong inhibition of barley root growth as a consequence of elevated $\mathrm{H}_{2} \mathrm{O}_{2}$ production through the root peroxidase system. Analogously, studies carried out by Grossmann et al. (2001) showed that auxin herbicides from different chemical classes caused reduction of internode elongation and stimulated $\mathrm{H}_{2} \mathrm{O}_{2}$ generation in Galium aparine L. shoot tissue. Moreover, results of Jin et al. (2010) indicated that herbicide ZJ0273 (a derivative of 2-pyrimidinyloxy- $N$-aryl benzoate) could deteriorate the enzymatic antioxidant system of rape plants, thereby exposing them to oxidative stress, by accumulating ROS, and ultimately affecting the plant growth. On the other hand, foliar application of 5-aminolevulinic acid (ALA; one of those plant growth regulators being used for stress amelioration) improved relative growth rate (root and shoot) of B. napus and also triggered the further accumulation of antioxidants activity, whereas decreased $\operatorname{ROS}\left(\mathrm{H}_{2} \mathrm{O}_{2}\right.$ and $\left.\mathrm{O}_{2}\right)$ production (Naeem et al. 2011; Zhang et al. 2008). 


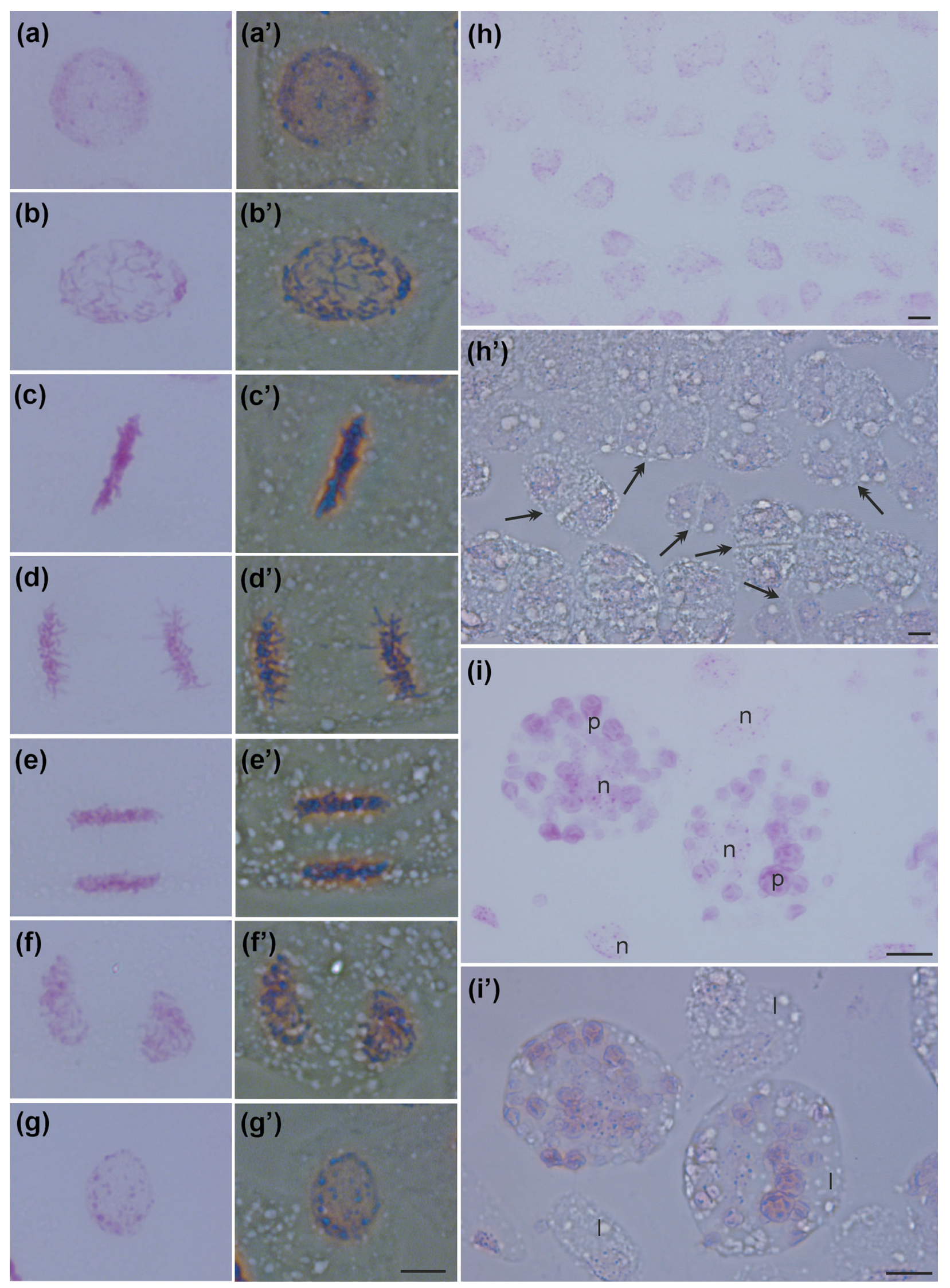




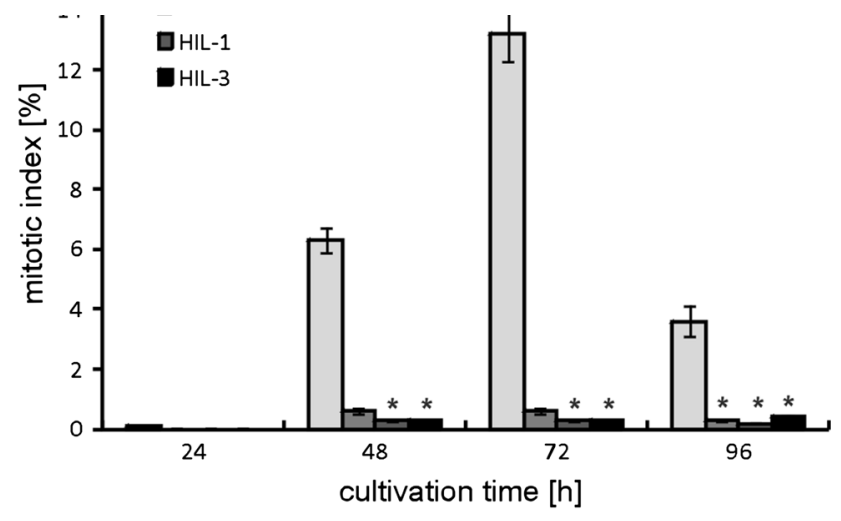

Fig. 9 Mitotic index $(\%) \pm \mathrm{SD}$ in root meristems of $B$. napus seedlings after 24, 48, 72 and $96 \mathrm{~h}$ of culture in distilled water. Before sowing the seeds were either soaked in distilled water (Control) or in the solutions of various herbicides: MCPA-salt (Chwastox Extra 300 $\mathrm{SL}^{\circledR}$ ) and MCPA in anion (HIL-1, HIL-3). Stars show the results where the differences are not statistically significant $(P=0.05)$
MCPA-ionic liquids (in particular HIL-3) used in these studies, caused a significantly weaker increase in the content of $\mathrm{H}_{2} \mathrm{O}_{2}$ in cells. Despite this they caused marked reduction of cell growth and inhibited elongation of roots. Research of Dunand and co-workers (2007) using $\mathrm{H}_{2} \mathrm{O}_{2}$ scavengers revealed that the decrease in the level of $\mathrm{H}_{2} \mathrm{O}_{2}$ was associated with intensification of cell and root elongation. In our study, lower levels of $\mathrm{H}_{2} \mathrm{O}_{2}$, generated by HILs did not correlate with cell and root elongation. On the contrary, cells were significantly shorter than those treated with conventional MCPA. These observations may indicate that mechanisms of HILs action differ from that of the traditional MCPA. On the other hand, in the HIL-treated roots significant (greater than under the influence of traditional MCPA) increase in the content of autofluorescent phenols was observed which may explain the low levels of $\mathrm{H}_{2} \mathrm{O}_{2}$ in cells. Phenols are effective scavengers of $\mathrm{H}_{2} \mathrm{O}_{2}$ because
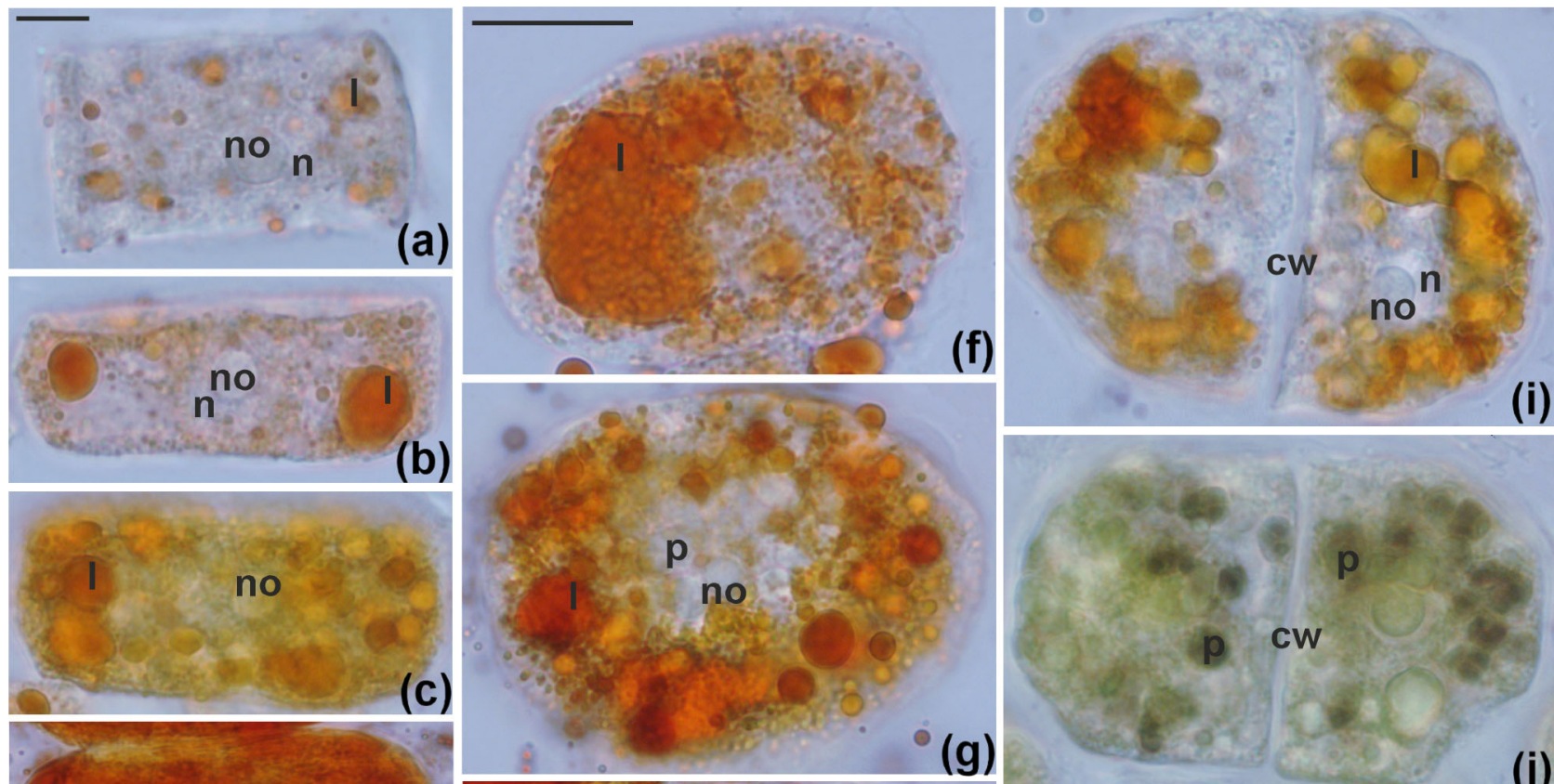

(i)
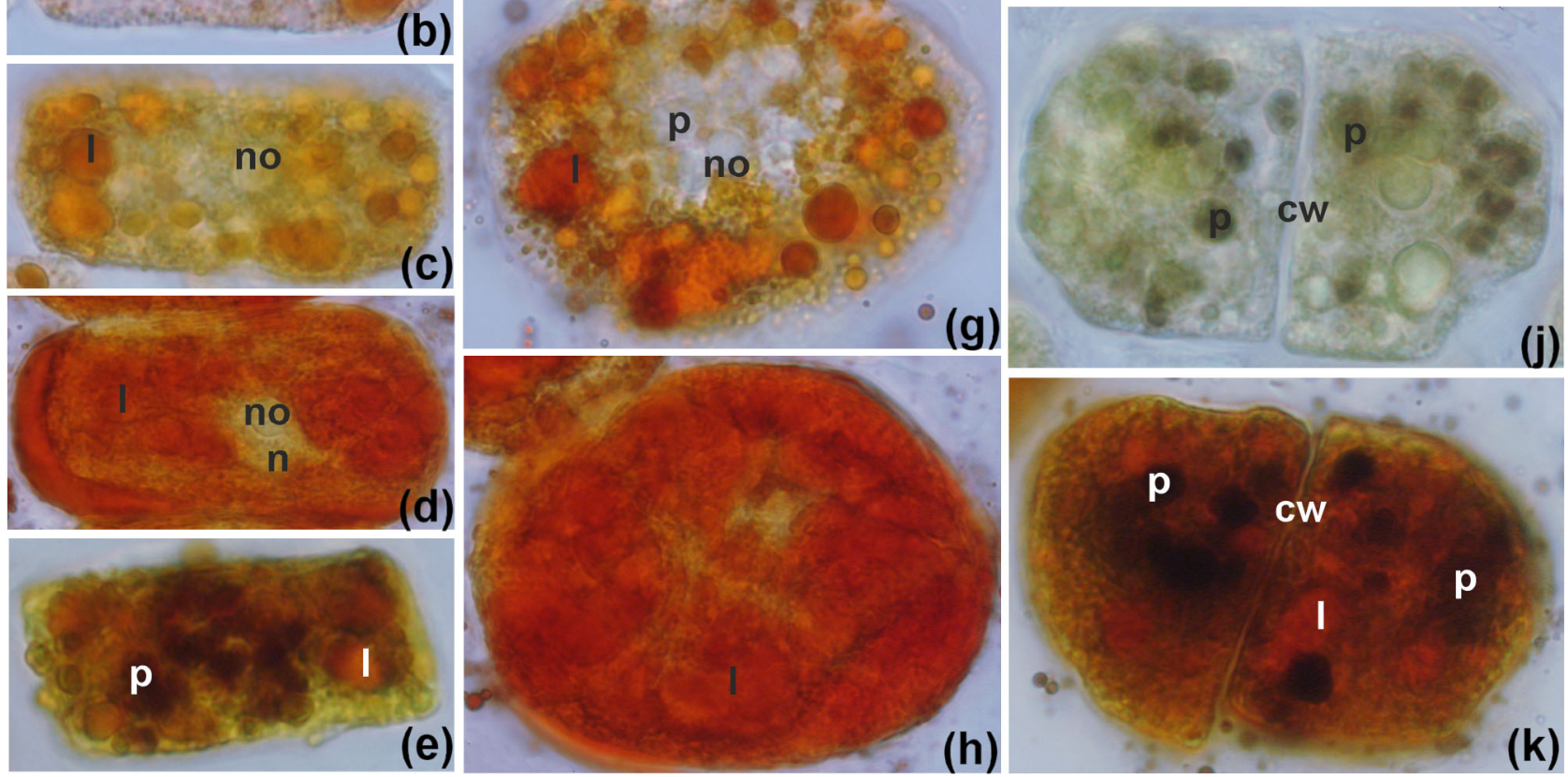

Fig. 10 Lipids (red, orange) and starch (dark) detected using the mixture of Sudan III and IV or Lugol's iodine solution, respectively, in B. napus root meristem cells (a-e) and in the cells from the bolded zone directly adjacent to the meristem $(\mathbf{f}-\mathbf{k})$ after $72 \mathrm{~h}$ of culture in distilled water. Before sowing the seeds were either soaked in distilled water (Control; a) or in the solutions of various herbicides: Chwastox Extra $300 \mathrm{SL}^{\circledR}(\mathbf{b}, \mathbf{f})$, HIL-1 (c, g), HIL-3 (d, h); $c w$ cell wall, $l$ lipids, $n$ nucleus, no nucleolus, $p$ plastids with starch grains. Bar $10 \mu \mathrm{m}$; bar in $\mathbf{a}$ also applies to $\mathbf{b}-\mathbf{e}$ and bar in $\mathbf{f}$ also applies to $\mathbf{g}-\mathbf{k}$ (colour figure online) 


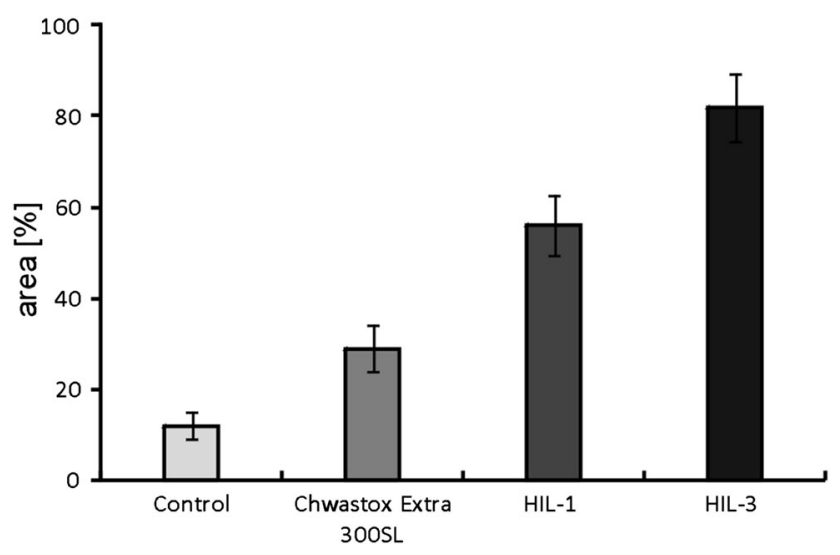

Fig. 11 The cell surface occupied by lipids (\%) \pm SD in root meristems of $B$. napus seedlings after $72 \mathrm{~h}$ of culture in distilled water. Before sowing the seeds were either soaked in distilled water (Control) or in the solutions of various herbicides: MCPA-salt (Chwastox Extra $300 \mathrm{SL}^{\circledR}$ ) and MCPA in anion (HIL-1, HIL-3)

peroxidases use $\mathrm{H}_{2} \mathrm{O}_{2}$ for their oxidation (Passardi et al. 2004; Michalak 2006; Dunand et al. 2007). Increased oxidation of phenols with peroxidases might be the reason why peroxidase is not involved in the production of $\mathrm{O}_{2}^{--}$required for root elongation in the elongation zone and hence we sow no root elongation (Dunand et al. 2007). Such a hypothesis seems possible but requires further confirmation. The precise role of phenolic substances in the processes of differentiation and morphogenesis is still not clear, but it is known that they play an important role in plant stress resistance. In the current study cells dealt with the excess of exogenous auxin, and it is known that phenols modulate the action of auxin. High levels of phenols, through lowering the endogenous IAA content, might maintain appropriate hormonal balance required for root induction (Volpert et al. 1995; Passardi et al. 2004; Michalak 2006; Dunand et al. 2007). Therefore, it seems possible, that in our study cells triggered the production of phenols in order to restore disturbed physiological balance. Studies of Lee (1977) showed that phenolic compounds such as chlorogenic, coffeic, and ferulic acid could interact with IAA oxidase to reduce the rate of auxin oxidation and hence their degradation. While Faivre-Rampant et al. (2002) suggested that high concentration of chlorogenic acid exceeding a certain threshold concentration could lead to the opposite effect and cause the inhibition of root development. Similarly, the study of Schnablová et al. (2006) showed that monophenolic acid stimulated IAA oxidase activity and thereby contributed to the degradation of auxin.

In the current studies, the lack of root growth under the influence of all applied auxin herbicides was also the consequence of almost complete inhibition of meristematic cell division. In the root meristems there were mainly interphase cells probably blocked in the principal control points of the cell cycle, i.e. in the G1 and G2 phase (Polit et al. 2003). No abnormal mitotic figures and chromosome aberrations such as: matted chromosomes, chromosome fragmentation and chromosome bridges were observed. They were reported earlier in the study of Sikka and Sharma (1976) and Kumar et al. (2010) who treated Allium cepa and Triticum aestivum plants with hormonal herbicides. On the contrary, in our results the interphase cells began to accumulate significant amounts of lipids and starch grains. As reported in contemporary literature auxins affect cell division and cell elongation differentially (Campanoni and Nick 2005; Tsugeki et al. 2009; Mithila et al. 2011). Auxin influence on cell division is mediated by a heterotrimeric G-protein whereas that on cell elongation is independent of this protein. Involvement of different receptors may be associated with binding of different ligands. Various auxins should therefore affect cell division and cell elongation with varying dose-response relations through different signal transduction pathways activated by different receptors (Campanoni and Nick 2005). Cytological examination showed that particularly cells treated with HIL-3 that had just passed telophase began rapid growth and accumulation of large amounts of lipids and starch becoming similar to parenchyma cells. Inhibition of cell division and accumulation of large cells in the absence of elongation of epidermal cells result in reduction of meristem and formation of characteristic protruding zone of root. It is also the reason for cracking and detachment root tips. These protruding root segments could also hinder normal development of a vascular tissue as did the abnormal structures formed in roots and shoots under the influence of aminocyclopyrachlor (Flessner et al. 2011). In the present study, it seems that the mechanism or way of standard and ionic MCPA transport-induced changes of varying intensity within the observed cells. Before herbicides reach their site of action they must overcome a number of barriers, both at the tissue level and within membranes of a single cell (Riechers et al. 1994; DiTomaso 1999). Charged molecules definitely influence the efficiency of transport (Zsoldos and Haunold 1979).

Our findings are significant for plant protection based on conjugated phenoxy herbicides because they can lead to long periods of stable and wider performance. Additionally low pricing, worldwide availability, high volume potential, safety for people/environment, cross between green solvents and surfactants are advantageous. The potential of ionic liquids to conceptually fulfil the requirements of environmental sustainability is remarkable.

Author contribution T. Praczyk, J. Pernak and E. Jakubiak prepared the new formulations of herbicides; $€$. Sobiech carried out, analysed and illustrated greenhouse and Petri dishes experiments; J.T. Polit planned, carried 
out, analysed, illustrated and described cytological part of the study; G. Skrzypczak was the initiator of research, prepared a theoretical introduction, modified the manuscript and supervised work.

Open Access This article is distributed under the terms of the Creative Commons Attribution License which permits any use, distribution, and reproduction in any medium, provided the original author(s) and the source are credited.

\section{References}

Campanoni P, Nick P (2005) Auxin-dependent cell division and cell elongation. 1-naphthaleneacetic acid and 2,4-dichlorophenoxyacetic acid activate different pathways. Plant Physiol 137:939-948

Cheng Y, Song C (2006) Hydrogen peroxide homeostasis and signaling in plant cells. Sci China Ser C Life Sci 49:1-11

Dat J, Vandenabeele S, Vranová E, Van Montagu M, Inzé D, Van Bresugem F (2000) Dual action of the active oxygen species during plant stress response. Cell Mol Life Sci 57:779-795

DiTomaso JM (1999) Barriers to foliar penetration and uptake of herbicides. Proc Calif Weed Sci Soc 51:150-155

Dunand Ch, Crèvecoeur M, Penel C (2007) Distribution of superoxide and hydrogen peroxide in Arabidopsis root and their influence on root development: possible interaction with peroxidases. New Phytol 174:332-341

Faivre-Rampant O, Charpentier J-P, Kevers C, Dommes J, Van Onckelen H, Jay-Allemand C, Gaspar T (2002) Cuttings of the non-rooting rac tobacco mutant overaccumulate phenolic compounds. Funct Plant Biol 29:63-71

Flessner ML, Dute RR, McElroy JS (2011) Anatomical response of St. Augustine grass to aminocyclopyrachlor treatment. Weed Sci 59:263-269

Foreman J, Demidchik V, Bothwell JHF, Mylona P, Mledema H, Torres MA, Linstead P, Costa S, Brownlee C, Jones JDG, Davies JM, Dolan L (2003) Reactive oxygen species produced by NADPH oxidase regulate plant cell growth. Nature 422:442-446

Gapper C, Dolan L (2006) Control of plant development by reactive oxygen species. Plant Physiol 141:341-345

Gechev TS, Hille J (2005) Hydrogen peroxide as a signal controlling plant programmed cell death. J Cell Biol 168:17-20

Grossmann K (2000) The mode of action of quinclorac: a case study of a new auxin-type herbicide. In: Cobb AH, Kirkwood RC (eds) Herbicides and their mechanisms of action. Sheffield Academic Press, Sheffield, pp 181-214

Grossmann K (2010) Auxin herbicides: current status of mechanism and mode of action. Pest Manag Sci 66:113-120

Grossmann K, Kwiatkowski J, Tresch S (2001) Auxin herbicides induce $\mathrm{H}_{2} \mathrm{O}_{2}$ overproduction and tissue damage in cleavers (Galium aparine L.). J Exp Bot 52:1811-1816

Hough WL, Rogers RD (2007) Ionic liquids then and now: from solvents to materials to active pharmaceutical ingredients. Bull Chem Soc Jpn 80:2262-2269

Hough WL, Smiglak M, Rodríguez H, Swatloski RP, Spear SK, Daly DT, Pernak J, Grisel JE, Carliss RD, Soutullo DM, Davis JH, Rogers RD (2007) The third evolution of ionic liquids: active pharmaceutical ingredients. New J Chem 31:1429-1436

Jin ZL, Zhang F, Ahmed ZI, Rasheed M, Naeem MS, Ye QF, Zhou WJ (2010) Differential morphological and physiological responses of two oilseed Brassica species to a new herbicide ZJ0273 used in rapeseed fields. Pestic Biochem Physiol 98:1-8

Kirchner B (2009) Ionic liquids. Springer, Berlin

Kumar S, Arya SK, Roy BK, Singh AK (2010) The effects of 2,4dichlorophenoxy acetic acid and isoproturon herbicides on the mitotic activity of wheat (Triticum aestivum L.) root tips. Turk J Biol 34:55-66

Kwak JM, Nguyen V, Schroeder JI (2006) The role of reactive oxygen species in hormonal responses. Plant Physiol 141:323-329

Lee TT (1977) Role of phenolic inhibitors in peroxidase-mediated degradation of indole-3-acetic acid. Plant Physiol 59:372-375

Maszewski J, Kaźmierczak A (1998) Repression of genetic activity in root meristem cells by peptidic factor derived from male sex organs of Chara. Biol Plant 41:357-368

Michalak A (2006) Phenolic compounds and their antioxidant activity in plants growing under heavy metal stress. Pol J Environ Stud 15:523-530

Mithila J, Hall JC, Johnson WG, Kelley KB, Riechers DE (2011) Evolution of resistance to auxinic herbicides: historical perspectives, mechanisms of resistance, and implications for broadleaf weed management in agronomic crops. Weed Sci 59:445-457

Mittler R, Vanderauwera S, Gollery M, van Breugesem F (2004) Reactive oxygen gene network of plants. Trends Plant Sci 9:490-498

Monaco TJ, Weller SC, Ashton FM (2002) Weed science: principles and practices. Wiley-Blackwell, New York

Naeem MS, Rasheed M, Liu D, Jin ZL, Ming DF, Yoneyama K, Takeuchi Y, Zhou WJ (2011) 5-Aminolevulinic acid ameliorates salinity-induced metabolic, water-related and biochemical changes in Brassica napus L. Acta Physiol Plant 33:517-528

Neill SJ, Desikan R, Clarke A, Hurst RD, Hancock JT (2002) Hydrogen peroxide and nitric oxide as signaling molecules in plants. J Exp Bot 53:1237-1247

Olivier-Bourbigou H, Magna L, Morvan D (2010) Ionic liquids and catalysis: recent progress from knowledge to applications. Appl Catal A 373:1-56

Passardi F, Penel C, Dunand Ch (2004) Performing the paradoxical: how plant peroxidases modify the cell wall. Trends Plant Sci 9:534-540

Passardi F, Tognolli M, De Meyer M, Penel C, Dunand Ch (2006) Two cell wall associated peroxidases from Arabidopsis influence root elongation. Planta 223:965-974

Pernak J, Syguda A, Janiszewska D, Materna K, Praczyk T (2011) Ionic liquids with herbicidal anions. Tetrahedron 67:4838-4844

Plechkova NV, Seddon KR (2008) Applications of ionic liquids in the chemical industry. Chem Soc Rev 37:123-150

Polit JT, Maszewski J, Kaźmierczak A (2003) Effect of BAP and IAA on the expression of G1 and G2 control points and G1-S and G2$\mathrm{M}$ transitions in root meristem cells of Vicia faba. Cell Biol Int 27:559-566

Praczyk T, Kardasz P, Jakubiak E, Syguda A, Materna K, Pernak J (2012) Herbicidal ionic liquids with 2,4-D. Weed Sci 60:189-192

Riechers DE, Wax LM, Liebl RA, Bush DR (1994) Surfactantincreased glyphosate uptake into plasma membrane vesicles isolated from common lambsquarters leaves. Plant Physiol 105:1419-1425

Rogers RD, Seddon KR (2003a) Ionic liquids as green solvents: progress and prospects. American Chemical Society, Washington DC

Rogers RD, Seddon KR (2003b) Ionic liquids—solvents of the future? Science 302:792-793

Schnablová R, Synková H, Vičánková A, Burketová L, Eder J, Cvikrová M (2006) Transgenic ipt tobacco overproducing cytokinins overaccumulates phenolic compounds during in vitro growth. Plant Physiol Biochem 44:526-534

Schoenwaelder MEA (2008) The biology of phenolic containing vesicles. Algae 23:163-175

Senseman SA (2007) Herbicide handbook. Weed Science Society of America, Lawrence 
Sikka K, Sharma AK (1976) The effects of some herbicides on plant chromosomes. Proc Indian Natl Sci Acad 42:299-307

Šimonovičová M, Huttová J, Mistrík I, Široká B, Tamás L (2004) Peroxidase mediated hydrogen peroxide production in barley roots grown under stress conditions. Plant Growth Regul 44:267-275

Thordal-Christensen H, Zhang Z, Wei Y, Collinge DB (1997) Subcellular localization of $\mathrm{H}_{2} \mathrm{O}_{2}$ in plants. $\mathrm{H}_{2} \mathrm{O}_{2}$ accumulation in papillae and hypersensitive response during the barley-powdery mildew interaction. Plant J 11:1187-1194

Tsugeki R, Ditengou FA, Sumi Y, Teale W, Palme K, Okada K (2009) NO VEIN mediates auxin-dependent specification and patterning in the Arabidopsis embryo, shoot, and root. Plant Cell $21: 3133-3151$
Volpert R, Osswald W, Elstner EF (1995) Effects of cinnamic acid derivatives on indole acetic acid oxidation by peroxidase. Phytochemistry 38:19-22

Vranová E, Inzé D, Van Brensegem F (2002) Signal transduction during oxidative stress. J Exp Bot 53:1227-1236

Wasserscheid P, Welton T (2008) Ionic liquids in synthesis. Wiley, Weinheim

Zhang WF, Zhang F, Raziuddin R, Gong HJ, Yang ZM, Lu L, Ye QF, Zhou WJ (2008) Effects of 5-aminolevulinic acid on oilseed rape seedling growth under herbicide toxicity stress. J Plant Growth Regul 27:159-169

Zsoldos F, Haunold E (1979) Effects of pH changes on ion and 2,4-D uptake of wheat roots. Physiol Plant 47:77-80 